\title{
Chapter 5 \\ Translating and Conveying the Damaging Childhood in Our Kate
}

\author{
Jo Parnell
}

\section{Women's Writing, Individuality, and Catherine Cookson}

Catherine (Kate) Cookson was born illegitimate and into poverty in the lower classes of the North East in England. As a child she had no authority over her own life, but as an author Cookson's experiences gave her the authority to write about the damaging childhood. In her autobiographical work Our Kate (1969), Cookson says she was always "fighting against what people were thinking ... "What chance did the lass have?"' (12-13). As Carolyn G. Heilbrun observes, until at least the late 1970s any woman of "accomplishment" had to confront masculine "power and control" in "trying to deal honestly with their past lives" (16-17). A woman who wrote a "truthful" autobiography, one that showed her individuality and highlighted deeper issues, was seen as imitating a masculine activity, and called "strident" (12-16). Apart from Robert Colls's scathing critique, Cookson was mainly ignored by male reviewers.

In the 1980s feminist critics, according to Linda Anderson, discovered a remarkable absence "of women's texts from an accepted canon of autobiographical writing" (86). Estelle Jelinek finds this absence was due to the predominant attitude amongst male critics that women's writing was "insignificant," and this was indicative of masculinist attitudes towards women's lives in general (4). Some feminist critics, Anderson included, felt that since autobiography "demonstrates that there are many different ways of writing the subject," women's autobiography should "be able to offer the woman reader a form of validation of herself, "the assurance ... that she does indeed exist in the world" (Anderson 87-8). Heilbrun agrees, and says that because critical theory is by tradition masculine-based, "reading women's lives needs to be considered in the absence of "a structure of critical" commonplaces (18-19). For Anderson, the question in relation to women's autobiography is "not so much what it is" but "what does it do" (91). Cookson defies male constructs, and she ignores the social conventions and theoretical thought of the day; so both those questions are applicable to her work.

Themes of illegitimacy, oppression, and the success of women in the face of adversity, run throughout Cookson's works. Bridget Fowler points out that 
Cookson's works were hugely popular with women readers (27). ${ }^{1}$ Sue Thornham, Elaine Brown, and Angela Werndly interviewed a number of Cookson's women readers from the North East; these readers "explicitly opposed Cookson's books" to the romances of Barbara Cartland, saying that unlike Cookson's works Cartland's romances were "not real life" and "not real enough for me" (143). They saw Cookson's works as "specifically female working class culture," and "about women, regardless of the men," and said they identify with Cookson and admire her strength, and want to be "that way," too (143). Quite possibly, this sense of "realness" is enhanced by a reader perception that Cookson's subject matter has its basis in her personal history as given out by her publishers on the covers of all her books. Anderson says, "if the writer is implicated in the work, any writing may be judged to be autobiographical, depending on how one reads it" (1). In her readers' eyes, Cookson's history would authorize her to write about the damaging childhood and the plight of working-class women.

In Our Kate Cookson does not focus on gender issues per se. However, as Leigh Gilmore notes, gender debate is a natural outcome of the genre; women's autobiography "is positioned within discourses that construct truth, identity, and power, and these discourses produce a gendered effect" (xiv). In Our Kate, in telling her personal story, Cookson exposes to the reader subjects previously held as taboo and puts a new slant on women's lives, gender issues, and the subject of the damaging childhood when she poses these central questions: "How do you assess the agonies of childhood? How do you go about putting them over?" She adds: "as a child you have as yet acquired no words to fit the pain" (81). Our Kate is a concrete demonstration of how to translate and convey the damaging childhood experience; the reader can "feel" what the experience is "like," "see" how it affects the mother's life and the child personally, and gain an idea of the legal, social, and political implications of illegitimacy.

The value of literary narratives like Cookson's lies in what Scott R. Stroud refers to as their ability to hold "the power to move individuals to thought, reflection, action, and belief" (19). In Our Kate, Cookson engages with the traumatic aspects of her childhood and endeavors to make sense of that experience through using the reflective voice. Writing about that type of experience in a literary narrative means being able to convince the reader that what they are reading contains truth; that the text is poetically true, and that the point of view is valid. Jane Taylor McDonnell adds that the reflective voice in creative work shows insight and understanding on the part of the author (quoted in Phelan 66). There is the further step for the writer in order to write with authority, which involves gaining the reader's attention and trust. Genres that deal with literary and extra-literary forms of authority make the "assumptions: that an individual's experience is communicable, and that ...

1 At the time of writing, the Booksellers Association of the UK and Ireland website, $<$ http://www.ewidgetsonline.com/vcil/bravenewworld.html $>$, has announced that 100 Catherine Cookson titles are about to be released as e-books. This implies that Cookson's works are still hugely popular with readers of all ages. 
even the most private and intimate experiences occur within the horizon of public understanding" (McCooey 3). I will focus on how Cookson constructs Our Kate and manipulates her reader to establish authority over the damaging childhood experience.

\section{Genre, Deception, and the Sources of the Power in the Writing}

In Our Kate Cookson follows her development as an artist, yet it would be misleading to call the work a Künstlerroman. Our Kate announces itself as an autobiography but nevertheless shares much with memoir. Gilmore notes that autobiography is "rooted in the confession" and hence is self-representational (112). Judith Barrington says that memoir is a "hybrid form with both elements of fiction and essay, in which the author's voice, musing on a true story, is all important" (20-22). But the story which eventually gets told, says Anderson, depends on which story the writer wishes to tell (1). Kathleen Jones says, "Autobiography of any kind ... is a species of fiction- [Our Kate] more than usually so" (4). Cookson's novelistic techniques make Our Kate more appealing and "get at" larger "truths" within the narrative. According to Theodore A. Rees Cheney the creative nonfiction writer may employ fiction techniques to make a character or a scene or setting appear more dramatic or more interesting or more real to highlight a point or get at larger "truths" (232). But to stay within the boundaries of ethics the writer must flag the reader as to what elements are fictional, and also "alert the reader" when she, or he, has crossed "over that fuzzy border into fiction territory" because the writer has a contract with the reader (232). Elsewhere, Cookson admitted to employing fiction techniques in Our Kate (Jones 4). But other than at the end of the work when she imagines a conversation with her deceased mother, Cookson does not alert the reader to this element in Our Kate; it is impossible to distinguish where the creative elements end and factual begins because Cookson's subjectivity is intrinsic and essential to the text.

To adapt H. Porter Abbott's words, Our Kate is "structured on the commonest of autobiographical masterplots: the effort to realize one's identity" (137). Our Kate is deceptive; it offers a difficult challenge in that Cookson's techniques makes a complex work appear simple. The apparent linearity of the story-line contains circular movements arising from Cookson's memories and a series of pivots which are based on her three crises of identity, and which keep the work's three intertwined strands, the sources of the power of the writing, in the reader's focus. The first source is the sense of enduring shame. The high-strung, sensitive child's consuming sense of shame pervades the entire work. The second source is Cookson's use of the temporal. The book is colored by her technique of centering the most damaging aspects of childhood on a highly imaginative child of about seven or eight years of age-all memories appear to radiate from, or be prompted by, the damaging incidents occurring around that time. The third source is the regional aspect. Throughout the book the reader is mindful of the impressionable 
child's emerging consciousness of region or place. It is necessary to attempt to tease out these strands one from the other in order to discuss how Cookson writes her memoir.

The "Kate" in the title of Our Kate is not Cookson herself but her mother. According to Marie Maclean, in autobiographies of illegitimacy "the very use" of the matronym marks "negation and difference" (44). In an autobiography such as Cookson's, the use of the matronym represents shame. Maclean also says that where a text such as a personal diary — for Cookson read personal history - is "designated by the first name alone," the "writer is entirely free to draw him [or her] self or to draw something other - or else to draw himself as other" (Derrida, cited in Maclean 4). By using the name "Kate" prefixed by the shared "our" as the title to her work Cookson is left free to redraw herself and her mother in the way she so wishes. By inviting the reader to focus on "our" Kate, and to a lesser extent on other characters while still referring to herself in first person, and by claiming ownership- "I," "me," "our," for example_Cookson makes "our" Kate's story her own (16-17). Gilmore likens the use of the personal pronoun in autobiographies of identity to a swinging door on the inner or private life, and the outer or public (autobiographical) life; the "symbolic function of [the] name obscures the differences ... between lived experience and autobiography ... by insisting that whatever the differences may be, their significance fails before the fallacy of autobiographical reference: the person" in both "is the same" (89). The reader "sees" "our" Kate and Katie McMullen-Cookson through the child's and hence Cookson's "eyes" precisely because the child and the adult and the mother are one.

Cookson writes Our Kate in first person but includes some third-person narrative. She employs a number of voices but focalization does not shift. The reader hears only the voice of Cookson relating chosen incidents that highlight the damaging impact of "our" Kate's actions on her childhood. In one scene "our" Kate corners and tries to kiss little Katie McMullen. Cookson writes: "the hateful smell of whisky wafted from her ... I wished she was dead" (49). Anderson says autobiography uses the self as a way to link discourse with convention and material location to say something that is "politically significant," and she uses Steedman's Landscape for a Good Woman as an illustration (110-11); Steedman notes that a memory of her father being caught illegally picking bluebells, and being humiliated by the forest-keeper as a consequence, "does not fit well" with the "theory of patriarchy" or the "generalized account of the centrality of the father's role within the family and culture" (112). Cookson does not enter into theoretical discourse or socio-political history in Our Kate as does Steedman in Landscape for a Good Woman, but the image Cookson paints of her drunken mother does not "fit well" with the theory of matriarchy or the "generalized account of the centrality" of the mother's role within the family and culture. Steedman, says Anderson, uses a central image of her mother "as a way of understanding her mother's desire and frustrations and formation within a specific class and economic terms" (112).

In Our Kate Cookson does likewise, and she excuses her illiterate, povertystricken mother's drinking to the reader when she says, "I was born when Kate 
was twenty-four and the life she was made to endure because of me would have driven anyone less strong ... into the madhouse" (16-17). To adapt Anderson's words on Steedman (112), Cookson's central image of "our" Kate also allows her, and the reader, to "see" Cookson's relationship with her mother as the passing on of a "deprivation" which is both material and psychological. "Our" Kate's "deprivation" manifests itself in hard drink; Cookson's manifests itself in the form of a nervous breakdown - and for which Katie McMullen-Cookson places the blame on "our" Kate, but which Cookson eventually grows to understand. Cookson's images of her mother allow her, and her reader, to understand "a social landscape," and through that, gain an understanding of Cookson the illegitimate child. This allows Cookson to "see" herself "in the picture" and move the child that was into the temporal.

\section{The Subjective and Intersubjective Nature of Our Kate}

Cookson's illegitimacy marked her as an outcast in the community in which she grew up. Even though she played with other children, she suffered the agonies of social exclusion. In Our Kate she writes: "in this chequered world ... I lived ... not of it, accepted, yet rejected" (21). In the final third of Our Kate, Cookson writes that in mid-life "I realized that a great deal of my mental trouble was that I was over sorry for this child ... Yet the pity for her was embedded in my system and I couldn't eradicate it just by willing it so, it would have to be worked out" by writing (222-3). Once, when asked if writing "autobiography was similar to writing fiction," Cookson replied: "No book that I have ever written has taken so much out of me as Our Kate ... . First [it was] bent on retaliation; secondly there wasn't one happy memory in it" (312). Cookson never stopped writing.

Anderson points out that "there is no singular text of the self ... which is only one's own" (84). Cookson's history, experiences, and feelings are not uncommon in society; thus, Cookson's Our Kate is intersubjective on both an individual and a collective level because once given a literary voice one's damaging childhood cannot remain private or entirely subjective. Indeed, Cookson did not intend her damaging childhood to be made anything other than public. In Our Kate she says that through her writing she was "going to get rid of the fear ... and in doing it ... help others" (231). Cookson adds that her work did help others: "I had letters from all kinds of people, all suffering" (231). Jones bears witness to Cookson's claim: "After the publication of Our Kate, Catherine's fan mail increased dramatically" (353). Cookson explains how it came about that she helped herself and others, but this does not explain the phenomenon of the relationship between the writer, her autobiography which involves identity, and the reader.

Our Kate is life writing. Cookson situates Our Kate in the interstices of memoir, trauma narrative, survivor narrative, and witnessing by placing her personal story in the historical context and relating it to the socio-economic climates and attitudes of the times and the area in which she lived. Cookson theoretically underpins her statements of intention in writing by bearing witness in her autobiographical- 
memoir, and by implicitly stating that Our Kate is a testimony to her unhappy childhood. Sidonie Smith and Julia Watson describe memoir as narrative in which the writer records personal memories in a way that "historically situates the subject in a social environment" (198). They describe trauma narrative as writing in which the narrator attempts to make sense of personal traumatic experiences, and witnessing as life-writing which gives testimony as "an act addressed to another ... getting beyond the repetition of trauma to a more humane ethically informed future" (206-7). In survivor narratives, the victims are remade by "telling their stories in ways that move beyond a concentration of personal feelings to testimony that critiques larger cultural forces" (207). Rosamund Dalziell says this happens because, "when the process of confronting shame and loss and of reviewing a life is represented in a text intended for the gaze of the benign reader, the autobiographer's narrating self is no longer isolated, having aligned him/herself with the other in regarding the shamed and abandoned narrating self" (261). Furthermore, when personal stories are moved "from the private to the public domain, they also move from the personal to the political" (Maclean 4).

Cookson reveals that because of her birth circumstances she faced educational, legal, and occupational barriers. In her introductory versified dedication to Our Kate, Cookson says it is not the illegitimates' fault that they face these hurdles, rather, it is a flaw within society and the "good men" "who make laws for bairns to keep"; she asks for the sake of all innocent children "who own no name" and hence "hide the shame of sin" and "carry the weight of guilt of censure and law," "that this law ... Be changed" (7). In this verse Cookson also begs understanding for unwed mothers and for herself: "The victim's vision is distorted / For in her mind / She is still ... the flyblow of a system" (7). Here is Cookson's comment on gender issues and the power of masculinist authority, and on the political and cultural forces which foster that oppression. Thus, this dedication brings the reader to a recognition - to adapt Jill Radford's words (46) — of the "limitations" of the law and legal processes "to provide adequate protection or redress for women" and their illegitimate offspring.

Cookson begins her story with the disclosure that all she ever wanted as a child was "to be called Mrs. because our Kate wasn't" (10). Throughout the book Cookson keeps this desire for a legitimate identity alive; and in the final third of the work, she mentions her marriage: "Katie McMullen is dead. ... Long live ... Mrs. Catherine Cookson" (204). Cookson writes that in mid-life she acknowledged the cause of her shame: "There, I had said it, aloud and in public, this frightening word ... that had brought ... shame into my life ... illegitimate" (251). Earlier in this essay I implied that in Our Kate, the illegitimate child carries the sins of the mother. "I am she" and "she is I." In the final pages of the book, in an imagined conversation with the deceased Kate, Cookson tells Kate that she has tried to be fair in her portrayal of their life together. The imagined Kate answers: "You always were fair, lass ... you haven't put down half that happened" (252). Cookson says she needed this spoken forgiveness in order to forgive herself: "I, too, needed saving" (240). In autobiographies of illegitimacy, says Maclean, an authorial 
signature which "makes a name the intermediary between public and private, empowers in as much as it acquires an identity from the texts it signs, just as it gives one to them" (5). In Our Kate, Cookson's marriage and Cookson's mother's death together form the point at which Cookson makes the reader aware that her complex work is striving to reach its implied purpose of seeking forgiveness in order to realize her identity. Without abandoning her mother and, hence, without abandoning herself by denying her own history, Cookson is striving to create for herself a new identity in the reader's eyes, and through that, legitimize herself through her writing, and recreate herself as "legal."

\section{Narratorial Distance, Authenticity, and Authority in Our Kate}

By writing an autobiographical memoir in which she recognizes her damaging childhood as the root cause of her past mental illness, and by writing her story from the stance of a middle-aged woman who claims she was emotionally ill but is now well, Cookson distances her damaging childhood by placing it in the past and recreating it as a sense of history. Thus, within the text of Our Kate Cookson creates a sense of the narratorial distance which Abbott says is necessary because it "affects the extent to which we trust the information we get from the narrator" (189). This technique enhances the illusion of truth. It gives Cookson the opportunity to tell her story in her own voice, and at the same time explore the child's subjective thoughts and feelings in order to convince her readers that her story contains literal truth.

In her autobiography Cookson gives the appearance that she is being honest, in seeming to reveal all as it happened, even though she imagines certain incidents or omits or alters certain facts. For example, Cookson's reader gains the impression that her doting grandma, Rose, died when Cookson was about eight, and that "someone" made her view the body: "the sight ... frightened me to death" (113). Not so, says Jones; Rose died when Katie was an angry, upset teen, and it was "our" Kate who forced her to view the decomposing body (81-3). Even so, since Cookson's grandmother did die when Cookson was a child and Rose's death did cause her enormous grief and fear, it seems feasible to use Abbott's words on an autobiography by W.N.P. Barbellion and say about Cookson's "lie" that "it is a falsehood which tells something of the truth" because, in the context within which it is used, "it reveals the intensity with which this autobiographer hoped to achieve some kind of tragic distinction" (135). The tragic distinction being Katie McMullen-Cookson's damaging childhood and feelings of loss of identity, both of which gave rise to her life-long feelings of shame. Abbott says that "when you narrate you construct ... narrative is always a matter of selecting from a great arsenal of pre-existing devices and using them to synthesize our effects" (64). In the context of a damaging childhood narrative like Cookson's, the image of a suffering, innocent young child is very likely to evoke reader sympathy for Katie McMullen-Cookson. By being honest in one way, but by placing the child at a 
young age, Cookson avoids alienating the reader as she might do if she used, say, an adolescent, more aware and self-pitying, child.

Cookson uses a number of methods to avoid alienating the reader; for instance, she sympathetically explains Kate's actions as understandable, and hence excusable, and also dwells on Kate's good points. Cookson begs the reader's forgiveness by openly admitting that, without realizing, she had indulged in selfpity over her damaging childhood: "It was my nature that revolted against her weakness" (107); the inference here is that through her attitude she inadvertently invited added pain. But because Cookson filters her agony of shame through "our" Kate's story and appears to tell the truth of the matter, her narrative confirms the authenticity of the work because it keeps its narrative "eye" focused on "our" Kate as the direct cause of Katie McMullen-Cookson's unhappiness (49). Possibly, Cookson's purpose is to secure reader understanding by binding her reality to the miserable life and poverty of the lower-class abandoned, unmarried mother and her illegitimate child; she says the fear of the workhouse was never far away (155). I suggest that Cookson made literary mileage out of elements of her personal history. In her memoir Cookson says her "grandfather" John McMullen had a lifelong fear of the workhouse; and for herself and her mother the workhouse could have been a possibility if Kate's parents had not given them a home. As well, it must not be forgotten that, as an adult, Cookson worked in Harton Workhouse as a laundry checker and saw how unmarried mothers and their children were treated: "Life in Harton Institution wasn't, I think, far removed from the time of Dickens" (169). ${ }^{2}$ It would seem that Cookson binds her reality to the workhouse to draw the reader's sympathy and admiration for herself.

Further to this, in Our Kate Cookson wins reader pity for Katie McMullen because she has her speak and act just as would a small innocent child in the given circumstances. McCooey refers to autobiographies that involve identity: "trust is an important feature of such autobiographical transactions. The element of trust required in a reader is also central." He adds that this "production of truth and authority ... "is not so much an exercise in capturing the self as capturing the reader, and the notion of authority suggests a public domain within which to be authoritative"" (1-2). In one passage in Our Kate, a small frightened Katie had not attended Mass as she said she had, and is bullied and humiliated by a teacher in front of the class. Cookson writes: "My legs would at this point have a great desire to cross themselves because my bladder was answering my nerves. I would move from one foot to the other and rub my knees together" (71). Anderson comments: "Picturing the self allows entry into the social, without losing specificity and individuality" (112). Thus, through a process of subjective simulation and "identification" with the child in the book, the reader is led to take Cookson at her word and feel sympathy, distress even, for poor little illegitimate Katie McMullen. In this way, Cookson creates a space in which to be authoritative and indicates to the reader that she is a trustworthy and reliable narrator.

2 Cookson's reference to Dickens adds yet another element to her memoir; in making the childhood of Katie McMullen comparable to one of Dickens's poor, illegitimate heroes, she sets the bar for suffering very high indeed. 


\section{Shame and the Use of the Temporal in Our Kate}

Katie McMullen-Cookson's agony of shame is the most powerful element in Our Kate. As a small child, Cookson was ashamed of being born into a lowerclass family; the fighting, rowing McMullen family were named as a "hard case," "dominated by drink," and not respected in the community $(22,169)$. Even though there were other McMullen relatives, Cookson says she "only felt responsibility for the people in our kitchen," that whatever else they were or were not, they were her people (21-2). The kitchen was the "hub" of her life and "the centre" of her universe from which "all pain and pleasure sprang" (79). In the kitchen she found a small security in the homely smell and taste of cooking, and pleasure in reading in front of the fire. It was also the place in which she witnessed drunken brawls and experienced and witnessed unlawful sexual advances, and where her battles with Kate ended in shame and humiliation. Thus, the kitchen locates and anchors Katie McMullen-Cookson's inner conflict and feelings of shame in place and narrative space.

Cookson adds weight to her story and the work's pervading sense of shame through the temporal aspect. She recalls that at three years of age, whenever she did not want to acknowledge someone or something, she imagined a picture: "I would turn my face to the wall; and always I would see a picture, which became the focal point of my striving, because it presented to me a different way of life. It showed me a big house peopled by ladies and gentlemen ... . Of course, I was in the picture, dead centre" (13). In like fashion, she places herself in her autobiography at approximately seven years of age, "dead center" in her picture of the damaging incidents which marked her childhood: "Incidents in my childhood keep moving in a circle round and round. When I focus on one ... I think it might have happened when I was seven and then I find it could only have happened when I was nine" (98). At each point of return to the child's most damaging experiences, Cookson either implies, or states, the child's age. She says she was not aware of the shame surrounding Kate, and hence herself, until she was seven or eight years of age when she was shocked to discover that "our" Kate, whom she admits she adored, but who later made her "sick with apprehension," drank. Cookson writes that she comforted herself with the thought that "she's not me ma, for I knew that the greatest disgrace in life was to have a ma who drank. ... [It] made people talk about you" $(29,74)$. Cookson then says that from the time she was seven or eight she was sent "almost every day of the week" to fetch the beer and became filled with shame: "It was looked on in some quarters as a disgrace" (47). This last remark is clearly that of the adult Cookson looking back on the situation. To adapt Anderson's words on Steedman, Cookson's child in Our Kate allows her, and her reader, to understand "a social landscape" from the perspective of "the social understanding of adulthood" which can then "be focused back on the image" to create a deeper understanding (112).

Cookson's centering and distancing techniques allow her to at once move the child into historical time and fix the maximum damage to the child at a point in 
chronological time. With Cookson, seven or eight years of age appears to be the age at which the highly strung, imaginative child is most vulnerable; even though she is not yet old enough to understand, Katie McMullen is not so young as to be unaware of what is going on. Cookson writes: "nothing you can do at that age had the power to convey the feeling of being buried under a tremendous weight of fear, of humiliation and shame" (81). Each time Cookson pulls the reader back to the young child's age, the return prompts a new run of memories which reach out and expand in a circular movement to encompass the long-lasting effects of her damaging childhood. For example, when Katie McMullen is seven years of age a playmate tells her, “your Kate's your ma ... an' ... You haven’t GOT NO DA, me ma says so" (30). About this, Cookson then says: "No one, unless he has been through a similar experience ... can have any idea as to ... [h]ow it shatters for always the whole world of childhood and reverberates through the rest of life" (30-31). After describing what the sudden "feeling of fear of not belonging" does to a child, Cookson returns to seven-year-old Katie McMullen's feelings of a new type of shame: "This mad startling piece of news ... sent my mind into a questioning dizzying strange world in which everybody's name was changed" (30-34). In her "secret" world of the lavatory, she reasoned that Kate could not be her mother because Kate was not married (31-32). Cookson says she filled in the gaps by playing a "pretence game" and creating a father for herself (33). Cookson reflects that she must have chosen the local doctor because "he was a very attractive [youngish] man" and "he had a car and this ... brought him into my picture on the wall" - a picture in which Cookson dreamt she was a child of nobility (33-34). Maclean writes that in Western European cultures, up until the seventeenth century, "only the father's blood" conferred "nobility" on offspring (44). Thus, Cookson's centering of the temporal aspect has the effect of tying the narrative and the memoir's central theme of shame together within the framework of Cookson's masterplot - the search for identity through legitimization.

Cookson also creates a penetrating atmosphere in Our Kate which reaches its zenith in a single incident which marks the heart of the book. Cookson infuses the passage with poignancy to form a connection between the narrative's emotive effects and the reader's subjective response. One Saturday Cookson says she found "our" Kate in the kitchen and asked for her clean Sunday pinny; and, being only eight, she neither really understood nor questioned Kate's "enigmatic" words: "It's no use, you know, hinny" (117). Cookson says she did not wait for an explanation because "one of the girls in Phillipson Street was having a birthday party," and even though she had not been invited she knew she would be going because all her playmates had been invited. Little Katie McMullen stood outside the kitchen door in the lane and waited until she saw her playmates appear, but they passed by without acknowledging her; Cookson writes with a touch of bitterness, "I might have been a brick wall for all the notice they took of me" (117). Determined to go to the party, little Katie McMullen refused to answer Kate's call but hurried down the back lane until she stood "opposite the back door of the party house" (117). Left outside alone, she tried to attract the attention of the party-goers by jumping 
up and down; "I knew that if anyone saw me they would tell Mrs. X and she would ... say, "Fancy me forgetting about you. Come on up, hinny"' (118). Cookson writes that she thought she had been accidentally overlooked, but the implication is that she knew she was being purposely ignored. This contradiction gives rise to a sense of mystery. It would seem that little Katie somehow knew that she would not be accepted, but knowingly refused to acknowledge it. About Katie's motives for wanting to go to the party, Cookson writes: "it was imperative I got into that party, because I had never been to a party except once when I was five" and "this party was different. It had been talked about for" weeks (117-8). Earlier, about a different matter, Cookson said: "I wanted to be looked up to" (13). The inference can be drawn that little Katie's true reasons for wanting to go to the party were that she felt she could not be admired if she was not acknowledged and included.

Cookson says that when she was left standing outside the party house, "There descended on me a feeling of desolation, of aloneness, it wasn't to be borne" (118). Unable to express her needs in any other way, little Katie "pushed open the yard door, went up the stone steps to the staircase door and knocked" (118). The party child answered the door and said that her mother had forbidden Katie to join in because "me ma says you haven't got no da" (118). Cookson does not forewarn her reader. Like Katie, the reader learns what is happening at the very moment it happens. The reader is almost as winded by the party-child's sudden pronouncement on the negative importance of Katie's illegitimacy as little Katie herself. Cookson shocks her reader into recognizing illegitimacy as a troubling issue on both a personal and social level, and hence convinces the reader that her narrative point of view is valid. Cookson writes: "I was no longer alone in my aloneness, for with me now was a concrete thing, it was hard and painful and its name was rejection and it was to gather to itself ... shame, anxiety, remorse and bitterness" (118-9). Cookson immediately follows up the partychild's cruel announcement of Katie's illegitimate status with a brief reflection upon childhood in a broader sense: "Children need no preliminary lead-up to vital statements, they simply make them" (118). Robert Scholes and Robert Kellog say that "the autobiographer ... seeks a pattern which drives him in the direction of generalization" (86). Cookson creates images of a small confused child taking action to solve her unhappiness and uses that to allow a more general connection by commenting on children's behaviour generally. Thus, Cookson makes her narrative at once specific and a mimetic presentation, and she uses the specific to draw her reader to a more generalized conclusion.

\section{Regionality and Identity}

In Our Kate Cookson writes that later in life, when she again came North to the place in which she grew up, she was approached after a function by a smiling woman whom she did not recognize but whose husband said: "But you must remember ... you picked tatties together in the cornfield" (243). Cookson says 


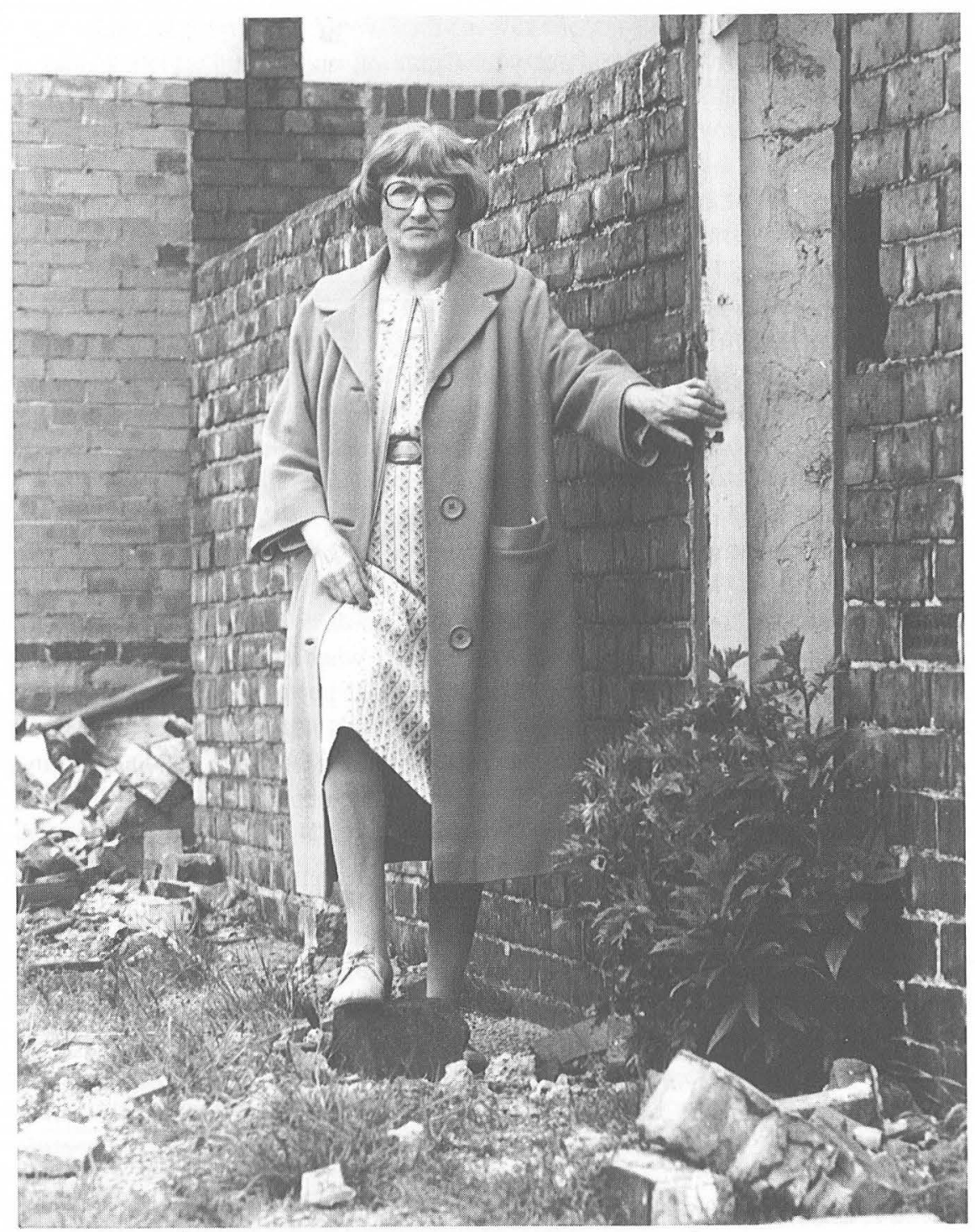

Fig. 5.1 Catherine Cookson standing among the ruins of William Black Street. Upon her return to the North East in 1976 she posed at the back door of the house where the childhood party to which she had not been invited took place. 
she had great trouble in trying to remember the woman but finally recalled her as "Bella Weir" (242-3). "It could only be," writes Cookson, that "she wasn't from the New Buildings" (243). This would seem to contradict what Cookson says earlier in her memoir: "My playmates in the New Buildings varied; sometimes it was one of the Weirs" (77). It is possible that Cookson only mentions the incident in order to assist her centering techniques and emphasize the regional aspect: "If ever before there had been a doubt in my mind about the hold that my earlier environment had on me this incident shattered it" (243-4). However, a few lines give the reader cause for doubt: "There I was ... Catherine Cookson, seven books to my name ... and here I was being reminded that I had picked tatties with this woman" (243). Jones says that from Cookson's account in a later interview it would seem that "when Bella spoke to her, all the pain of her childhood rose up in front of her" (363). "Bella" was the child who had first informed Katie McMullen that she was illegitimate.

Jones reveals that while Cookson was in the North there was a similar incident at a book-signing; Cookson was approached by a woman called Cecilia - this woman was the child who had refused Katie entry to her birthday party: "Catherine denied ever knowing her. When a bewildered Cecilia insisted that they had been best friends ... Catherine turned her back. She ... would later admit that she had 'a sort of talent for hatred"' (70). In Our Kate Cookson does not at any time mention the names of the girls who had hurt her when she was a child, and she makes a point of forgetting "Bella's" name. The reasons are psychologically complex. Cookson worked hard to rise above her beginnings and achieve a "ladylike veneer,"3 but she could not rid herself of her shame of being born illegitimate. Her childhood feelings of rejection and her perceptions of her illegitimate status gave rise to a subconscious need to be acknowledged so that she could stand above her peers and shine. As an adult, and a famous one at that, she could not look down her nose at her former peers if she was reduced to acknowledging them as friends. It is probable, too, that Cookson saw their overtures as hypocrisy; they had rejected her when she was a poor, little illegitimate, but wanted to be associated now that she was famous.

Possibly, as the writer of Our Kate, Cookson feared that too truthful exposure would result in too much bitterness in her narrative, and hence lessen her reader's sympathetic empathy. Earlier in this essay I said that in Our Kate Cookson makes Kate's story inseparable from her own. Jones writes that in an interview with Professor Ernst Honigmann of Newcastle University, "Catherine" admitted "that she had used her novelist's art to tell a story ... 'not that Our Kate wasn't the real facts, but ... if I had portrayed Kate as she was ... she wouldn't have appeared as good" " (402). Further to this, there is the question of Cookson's "gentleman" father. Jones says Cookson did not wish to know her father's true identity, that Cookson "preferred living with the fantasy to risking the discovery of an uncomfortable

3 In a later book, Plainer Still, Cookson writes: "I was an upstart playing at being a lady ... I actually was, a self-educated illegitimate" (1996: 36). 
truth" (354). The inference can be drawn that in Our Kate Cookson purposely created a legend that would not only cast her in a good light - and a romantic one at that-but which would also show "them."

As another source of the power of the writing in Our Kate, regionality ties "our" Kate to the masterplot - Cookson's search for identity. Katie McMullenCookson cannot identify with her mother in real life: "One person I dared not think about was Kate" (220). Nor can she identify with her unknown father other than in her imagination: "the sketchy outline of my beginnings ... set up in my mind ... a sense of false superiority" (18-19). She suffers three agonizing identity crises. The first is in childhood; at seven and eight years of age Katie McMullen learns for the first time about her illegitimacy and its accompanying rejection is brought home to her $(30,118)$. This initial identity crisis sparks a second; when Katie McMullen is 13 or 14 years of age she suffers a nervous breakdown, which, even though it coincides with a bout of physical illness, is precipitated by the shame of "our" Kate and her own illegitimacy (132-6). Katie McMullen-Cookson suffers a third identity crisis in adulthood; this takes the form of recurring mental problems that stem from her childhood crises of identity, and is not helped by bouts of serious physical illness. ${ }^{4}$ Thus, the emotional crisis that Cookson underwent in childhood gathered momentum in adolescence and precipitated a reasonably serious nervous breakdown in adult life (214). She recovered, she says, because she openly and publically admitted to her beginnings - to being a "child of the Tyne" (251).

Towards the end of her book Cookson says she knew she was "born to write" but also knew that she "wouldn't write a word that anyone would really want to read until I threw off the pseudo-lady and accepted my early environment, me granda, the pawn, the beer carrying, the cinder picking, Kate's drinking, and of course my birth, for it was these things that had gone to make me" (224). Cookson draws vivid word pictures of the area in which she was born and lived, and the characters in Our Kate speak in the dialects of the Geordie areas in which she grew up. But there is a marked difference between how her characters speak and the educated way in which she writes. Cookson the articulate writer explains how

4 Cookson had Hereditary Haemorrhagic Telangiectasia, a genetic blood disorder which caused spontaneous haemorrhaging and resulted in severe anaemia, and which she says could only have been inherited from her "unknown" father (Our Kate, 1988: 250). Cookson also reveals that she suffered four devastating miscarriages, and was rhesus negative (235). She claims to have had lead poisoning (145); cordite poisoning, and phlebitis (210); "a painful [nasal] antrum," neuritis, and a skin allergy (231); double pneumonia, and severe allergic reactions to various drugs (235); bad eyesight (184); and stomach trouble (186). Later in the book she writes that she "wouldn't wish the devil in hell to have a breakdown," but if she had a choice between that and "crippling, agonizing physical disease," she'd choose the physical disease "without hesitation" (214). It would seem that to Cookson, physical illness was socially acceptable whereas mental illness was shaming: "another fear added to the rest ... people knew about me being ill ... I was indignant that they should have thought I had been in an asylum - I hadn't ... I had been a voluntary patient and had private treatment in a home for nerve cases" (216). 
the poor worked the system by pawning goods, even something as essential as a "gully," a bread knife, in order to live (22); to be "mortallious" is to be rolling rotten with drink (38); "panhacklety" and "finnie-haddie" are dishes common to the northern areas - the smell and taste of which colored her damaging childhood with a small sense of security (64); and she explains the Geordie differentiation between using the prefix "me" to refer to those relatives living in the house, and "my" to indicate relatives who live elsewhere (22). Thus, regionality anchors the memoir's pivotal elements and temporality and the child's sense of "universe" in place and runs throughout the book on a parallel with shame. Our Kate, even with its universal resonance, clearly shows that Cookson is a "child" of the North, a regional writer who never escapes her destiny.

\section{Cookson's "Voices" and the Damaging Childhood}

In the final pages of Our Kate Cookson enters a world of make-believe where her mother says: "because you've learnt to forgive things will settle in you now." Cookson replies: "I don't know. I've still a long way to go" (252). That Cookson continued to seek personal atonement through her writing is verified by her later, non-fiction works, Let Me Make Myself Plain (1988) and Plainer Still (1996). In both, Cookson backs up incidents mentioned in Our Kate in calmly narrated facts and anecdotes, but the voice is that of an aged woman trying to come to grips with inner conflicts that had their roots in her childhood. In both books, Cookson talks to the reader woman to woman; she discusses her husband in indulgent tones, enlarges upon her childhood and later experiences in a friendly manner, and generally tries to present herself to her readers as a woman who is just like any other. And, as she does in Our Kate, Cookson uses her centering techniques to pull the reader back to her damaging childhood: "You know, we are all what our early environment makes us" (Let Me Make Myself Plain, 1988: 32).

By the 1980s, after having read Our Kate or even just the jackets of her novels, Cookson's readers already knew of her illegitimacy. So Cookson's two later works do not allow the same sense of mystery as Our Kate. Even so, Cookson seems to promote herself as being "different"- more ill, more admirable, more spiritually strong than her readers, saintly but humble, and privy to the supernatural. In Let Me Make Myself Plain Cookson says, once, while she was haemorrhaging, she heard a disembodied voice saying: "Get up and go into the garden and put your hands into the earth"'; she followed its instructions, the bleeding stopped, and she was saved from an imminent and unpleasant operation (159-60). The later books are awash with Cookson's blood, so to speak. She seems almost to sigh and roll her eyes as she asks the reader: "How on earth do I survive these things?"- - the damaging childhood, the inherited diseases, the "nerves," the haemorrhaging, and the anaemia; she adds: "I am not asking ... out of any feeling of pity for myself, but I would like to know where came the strength that has enabled me to still be here" (Plainer Still, 1996: 221). She answers her own question thus: "I can only 
think that the answer lies in the spirit, that intangible, elusive quality that cannot be claimed as part of one's character, but" is a universal gift of power-which is left "untapped" by many (221). In Plainer Still she says there was a "presence" in her house (179-87); and there was the sweet scent of flowers around her presence in the absence of flowers (183-9). ${ }^{5}$ Cookson says she told the priest, and he said: "'I knew it. I've been telling you for ages"; Cookson replied, "Don't you start sticking me up with the saints again, or I won't believe a word your saying"; and the priest said: “'Don't believe me ... read the life of Saint Thérèse of Liseux. The very same thing happened to her."' (188). Gilmore notes that in many women's autobiographies the discursive setting has its roots in a rhetorical form which appeals to the authority of a higher power and confirms the confessor as a teller of truth and, hence, a powerful and legitimate identity (111). Possibly, Cookson created this sense of spiritual mystery to establish herself in her readers' eyes as the chosen "One."

By the time Let Me Make Myself Plain and Plainer Still were released, women writers had begun to come into their own and illegitimacy had started to lose its "ooh-aah" factor; the change which Heilbrun "arbitrarily" identifies as beginning in the 1970s and which heralded a shift in gender issues which had ramifications for society and political matters, was already in full swing (12-13). It is possible that after the success of Our Kate Cookson needed to create a new legend to keep her damaging childhood and herself in the reader's focus. It is equally possible that Cookson genuinely felt that she had suffered, and still suffered, more than any one of her readers, and that this gave her the authority to continue writing about the damaging childhood. I also suggest that Cookson's desire to represent herself as different from others stems from her childhood insecurities and her need for admiration. In Let Me Make Myself Plain Cookson writes that when her first book was published in 1950 she "imagined that everyone would joy" with her; "but to my amazement only a small percentage of my ... so-called friends, came up to my expectations ... not one word was said about Catherine Cookson's great achievement" (123). Yet again, Cookson points the reader back to her damaging childhood, and hence back to the child in Our Kate: "I wanted to be looked up to ... even envied" (13). In yet another memoir, Catherine Cookson Country: Her Pictorial Memoir, Cookson says: "Here I am at seventy-one and I know that inside I am still very much ... Katie McMullen of East Jarrow ... I am still hurt as she was hurt" (186). It seems that with Cookson, fan mail was deeply satisfying but the admiration and envy of her "friends" was imperative to her picture of acceptance as a legitimate identity.

What Cookson does in Our Kate is construct a formal picture of the attitudes and inadequate practices of her times in combination with the subjective thoughts and feelings and personal experiences of the suffering child; and in so doing gives to the reader a convincing picture of the horrors and effects of the damaging childhood from within a social context. Cookson creates a space in which to be authoritative;

5 Cookson seems to ignore possible scientific explanations. For instance, a "doctor friend" told her "it's to do with the sex glands"; she says, "I didn't believe him" (184). 
she takes the raw material of the experience and re-imagines it in such a way that enables readers to reconstruct the experience as their own. By constructing Our Kate in the way that she does, Cookson demonstrates her individuality as a writer. Nevertheless, Cookson's numerous novels and her repeated attempts at memoir bear witness that, for Cookson, the question of identity and authority is never quite resolved.

\section{Works Cited}

Abbott, Porter H. The Cambridge Introduction to Narrative (Cambridge: Cambridge University Press, 2002).

Anderson, Linda. Autobiography (London: Routledge, 2001).

Barrington, Judith. Writing the Memoir (Sydney: Allen \& Unwin, 2000).

Benstock, Shari (ed.). The Private Self (Chapel Hill: University of North Carolina Press, 1988).

Cheney, Theodore A. Rees. Writing Creative Nonfiction: Fiction Techniques for Crafting Great Nonfiction (Berkeley: Ten Speed Press, 2001).

Colls, Robert. "Cookson, Chaplin and Common: Three Northern Writers in 1951," in K.D.M. Snell (ed.), The Regional Novel in Britain and Ireland, 1800-1990 (Cambridge: Cambridge University Press, 1998), pp. 164-200.

Cookson, Catherine. Our Kate: An Autobiography [1969] (London: Corgi Books, 1988).

. Catherine Cookson Country: Her Pictorial Memoir (London: William Heinemann Ltd, 1986).

—. Let Me Make Myself Plain: A Personal Anthology (London: Bantam Press, 1988).

- Plainer Still: A New Personal Anthology (London: Corgi Books, 1996).

Dalziell, Rosamund. Shameful Autobiographies: Shame in Contemporary Australian Autobiographies and Culture (Carlton South: Melbourne University Press, 1999).

Dudgeon, Piers. Kate's Daughter: by the Real Catherine Cookson. Read by Susan Jameson (CD-ROM, 5 discs. Bath: BBC Audiobooks, 2004).

Fowler, Bridget. The Alienated Reader: Women and Popular Romantic Literature in the Twentieth Century (Hertfordshire: Harvester Wheatsheaf, 1991).

Gilmore, Leigh. Autobiographics: A Feminist Theory of Women's SelfRepresentation (Ithaca, New York: Cornell University Press, 1994).

Heilbrun, Carolyn G. Writing a Woman's Life (New York: W. W. Norton, 1989). Jelinek, Estelle C. (ed.). Women's Autobiography: Essays in Criticism (Bloomington: Indiana University Press, 1980).

Jones, Kathleen. Catherine Cookson: the Biography (London: Warner Books, 2000).

McCooey, David. "Going Public: A Decade of Australian Autobiography," Australian Book Review (April 2006): 1-9, <http://home.vicnet,net. au/ abr'May06/McCooey\%20essay.html> (accessed October 15, 2008). 
Maclean, Marie. The Name of the Mother: Writing Illegitimacy (London: Routledge, 1994).

Phelan, James. Living to Tell about It: A Rhetoric and Ethics of Character Narration (Ithaca, New York: Cornell University Press, 2005).

Radford, Jill. "History of Women's Liberation Movements in Britain," in Gabriele Griffin, et al. (eds), Stirring It: Challenges for Feminism (London: Taylor \& Francis, 1994), pp. 40-58.

Scholes, Robert, and Robert Kellog. The Nature of Narrative (Oxford: Oxford University Press, 1968).

Smith, Sidonie, and Julia Watson. Reading Autobiography: A Guide for Interpreting Life Narratives (Minneapolis: University of Minnesota Press, 2001).

Stroud, Scott R. "Simulation, Subjective Knowledge, and the Cognitive Value of Literary Narrative," The Journal of Aesthetic Education, Vol. 42:3 (Fall 2008): $19-41$.

Thornham, Sue, et al. "'Not Happy but Hopeful': Readers of Catherine Cookson in the North-East of England," in Gabriele Griffin, et al. (eds), Stirring It: Challenges for Feminism (London: Taylor \& Francis, 1994), pp. 142-55. 